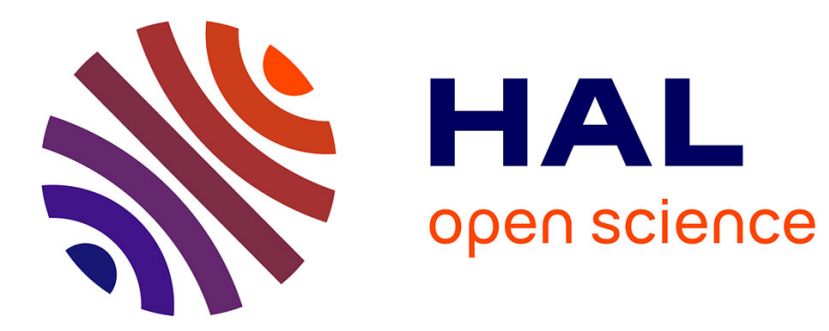

\title{
Estimation of unknown inputs in linear systems
}

\author{
Didier Maquin, Besma Gaddouna, José Ragot
}

\section{To cite this version:}

Didier Maquin, Besma Gaddouna, José Ragot. Estimation of unknown inputs in linear systems. American Control Conference, ACC'94, Jun 1994, Baltimore, United States. pp.1195-1197, 10.1109/ACC.1994.751939 . hal-00201423

\section{HAL Id: hal-00201423 \\ https://hal.science/hal-00201423}

Submitted on 17 Apr 2014

HAL is a multi-disciplinary open access archive for the deposit and dissemination of scientific research documents, whether they are published or not. The documents may come from teaching and research institutions in France or abroad, or from public or private research centers.
L'archive ouverte pluridisciplinaire HAL, est destinée au dépôt et à la diffusion de documents scientifiques de niveau recherche, publiés ou non, émanant des établissements d'enseignement et de recherche français ou étrangers, des laboratoires publics ou privés. 


\title{
Estimation of unknown inputs in linear systems
}

\author{
Didier Maquin, Besma Gaddouna and José Ragot \\ Centre de Recherche en Automatique de Nancy \\ 2, Avenue de la Forêt de Haye, BP 3 - Vandoeuvre lès Nancy - France \\ Phone: (33) $83595959 \quad$ Fax: (33) 83595644 \\ Email: \{dmaquin, bgaddoun, jragot\}@ensem.u-nancy.fr
}

\begin{abstract}
A systematic design procedure is developed for determining unknown inputs of a dynamic system. The results presented in this paper can be used directly for the design of fault detection and isolation observers for systems with unknown inputs or for systems with faulty inputs.
\end{abstract}

\section{Introduction}

In the last several years, considerable attention has been focused on the design of observer for linear systems with unknown inputs. Johnson (1975) and Hostetter (1973) proposed methods which assume some a priori knowledge about the unmeasurable inputs; this may impose some limitations. Kobayashi (1982) suggested an approach which follows Silverman's system inverse method. Using the simplest matrix generalised inverse, a procedure has been established by Miller (1982) for the construction of a reduced-order Luenberger observer. Necessary and sufficient conditions for the existence of an observer for linear multivariable systems with unknown inputs have been presented by Kudva (1980) and Kurek (1983). Fairman (1984) proposed a method of designing a Luenberger observer capable of determining the state of a system having some inputs which are completely unknown; this method is based on singular value decomposition technique. Yang (1988) developed a direct design procedure of a full order observer using straightforward matrix calculation. The case of singular systems with unknown inputs has been discussed by Yang (1989). Recently, Hou (1992) suggested a design of reduced-order observer with some comparison within the framework of descriptor system observers design principles.

In that recent paper, Hou presents a design of reduced-order observers for linear systems with unknown inputs. He proposes to decompose the state equation of the system into two subsystems; the first one depends on the unknown inputs and, in the second one, the unknown inputs may be dropped. Under the assumption that the state of the second subsystem may be obtained through the measurement equation, he designs a reduced-order observer for the unknown inputs. However, they are many situations in which this hypothesis does not hold and therefore we suggest an alternative method.

In this paper, the procedure proposed by Hou is briefly presented with some modification, then a straightforward treatment allowing the unknown input estimation is proposed.

\section{The basic procedure}

Consider the linear time-invariant system

$\mathrm{x}(\mathrm{k}+1)=\mathrm{A} \mathrm{x}(\mathrm{k})+\mathrm{B} \mathrm{u}(\mathrm{k})+\mathrm{D} \mathrm{d}(\mathrm{k})$

$\mathrm{y}(\mathrm{k})=\mathrm{C} \mathrm{x}(\mathrm{k})$

where $\mathrm{x} \in \mathrm{R}^{\mathrm{n}}, \mathrm{u} \in \mathrm{R}^{\mathrm{p}}, \mathrm{y} \in \mathrm{R}^{\mathrm{m}}, \mathrm{d} \in \mathrm{R}^{\mathrm{s}}$ are respectively the state vector, the input vector, the measurement vector and the unknown input vector. The matrices A, B, C and $\mathrm{D}$ are constant with appropriate dimensions. Without loss of generality, we assume that $\mathrm{C}$ is a full row rank matrix and that $\mathrm{D}$ is a full column rank matrix. This last assumption yields the decomposition:

$\mathrm{D}=\mathrm{H}\left(\begin{array}{l}\mathrm{R} \\ 0\end{array}\right) \mathrm{K}^{\mathrm{T}}$

where $H \in \mathrm{R}^{\mathrm{n} . \mathrm{n}}, \mathrm{R} \in \mathrm{R}^{\mathrm{s} . \mathrm{s}}, \mathrm{K} \in \mathrm{R}^{\text {s.s }}$.

The system (1) is restricted system equivalent to:

$\overline{\mathrm{x}}(\mathrm{k}+1)=\overline{\mathrm{A}} \overline{\mathrm{x}}(\mathrm{k})+\overline{\mathrm{B}} \mathrm{u}(\mathrm{k})+\left(\begin{array}{l}\mathrm{R} \\ 0\end{array}\right) \overline{\mathrm{d}}(\mathrm{k})$

$\mathrm{y}(\mathrm{k})=\overline{\mathrm{C}} \overline{\mathrm{x}}(\mathrm{k})$

where:

$\begin{array}{lll}\overline{\mathrm{A}}=\mathrm{H}^{\mathrm{T}} \mathrm{AH} & \overline{\mathrm{B}}=\mathrm{H}^{\mathrm{T}} \mathrm{B} & \overline{\mathrm{C}}=\mathrm{CH} \\ \overline{\mathrm{x}}(\mathrm{k})=\mathrm{H}^{\mathrm{T}} \mathrm{x}(\mathrm{k}) & & \\ \mathrm{d}(\mathrm{k})=\mathrm{K}^{\mathrm{T}} \mathrm{d}(\mathrm{k}) & \end{array}$

The partitioning of $\overline{\mathrm{x}}$ into $\left(\overline{\mathrm{x}}_{1} \quad \overline{\mathrm{x}}_{2}\right)^{\mathrm{T}}$ where $\overline{\mathrm{x}}_{1} \in \mathrm{R}^{\mathrm{s}}$ and

$\overline{\mathrm{x}}_{2} \in \mathrm{R}^{\mathrm{n}-\mathrm{s}}$, points out the decomposition of the system (3) into an unknown-input depending subsystem and an unknown-input-free subsystem:

$\overline{\mathrm{x}}_{1}(\mathrm{k}+1)=\overline{\mathrm{A}}_{11} \overline{\mathrm{x}}_{1}(\mathrm{k})+\overline{\mathrm{A}}_{12} \overline{\mathrm{x}}_{2}(\mathrm{k})+\overline{\mathrm{B}}_{1} \mathrm{u}(\mathrm{k})+\mathrm{R} \overline{\mathrm{d}}(\mathrm{k})(5 \mathrm{a})$

$\overline{\mathrm{x}}_{2}(\mathrm{k}+1)=\overline{\mathrm{A}}_{21} \overline{\mathrm{x}}_{1}(\mathrm{k})+\overline{\mathrm{A}}_{22} \overline{\mathrm{x}}_{2}(\mathrm{k})+\overline{\mathrm{B}}_{2} \mathrm{u}(\mathrm{k})$

$\mathrm{y}(\mathrm{k})=\overline{\mathrm{C}}_{1} \overline{\mathrm{x}}_{1}(\mathrm{k})+\overline{\mathrm{C}}_{2} \overline{\mathrm{x}}_{2}(\mathrm{k})$

with $\mathrm{C}_{1} \in \mathrm{R}^{\mathrm{m} . \mathrm{s}}$ and $\mathrm{C}_{2} \in \mathrm{R}^{\mathrm{m} \text {.(n-s) }}$.

As $\mathrm{R}$ is a regular matrix, the equation (5a) may be used to estimate the unknown input $\mathrm{d}(\mathrm{k})$ (or equivalently $\mathrm{d}(\mathrm{k})$ ) . Under the assumption that the state $\overline{\mathrm{x}}_{1}(\mathrm{k})$ may be obtained from $\mathrm{y}(\mathrm{k})$, equations $(5 \mathrm{~b})$ and $(5 \mathrm{c})$ describe a dynamic linear system which depends on $\overline{\mathrm{x}}_{2}(\mathrm{k})$ only. Thus, following Hou and Müller works, $\overline{\mathrm{C}}{ }_{1}$ is supposed to be a full column rank matrix and may be expanded as:

$\overline{\mathrm{C}}_{1}=\mathrm{H}_{1}\left(\begin{array}{c}\mathrm{R}_{1} \\ 0\end{array}\right) \mathrm{K}_{1}^{\mathrm{T}}$ 
with $\mathrm{H}_{1} \in \mathrm{R}^{\mathrm{m} . \mathrm{m}}, \mathrm{R}_{1} \in \mathrm{R}^{\mathrm{s} . \mathrm{s}}$ and $\mathrm{K}_{1} \in \mathrm{R}^{\mathrm{s} . \mathrm{s}}$. Let us consider the partition $\mathrm{H}_{1}=\left(\begin{array}{lll}\mathrm{H}_{11} & \mathrm{H}_{12}\end{array}\right)$ where $\mathrm{H}_{11} \in \mathrm{R}^{\mathrm{m} . \mathrm{s}}, \mathrm{H}_{12} \in$ $\mathrm{R}^{\mathrm{m} .(\mathrm{m}-\mathrm{s})}$ and the transformed output $\overline{\mathrm{y}}(\mathrm{k})=\mathrm{H}_{1}^{\mathrm{T}} \mathrm{y}(\mathrm{k})$. Then, the measurement equation may be decomposed:

$\overline{\mathrm{y}}_{1}(\mathrm{k})=\mathrm{R}_{1} \mathrm{~K}_{1}^{\mathrm{T}} \overline{\mathrm{x}}_{1}(\mathrm{k})+\mathrm{H}_{11}^{\mathrm{T}} \overline{\mathrm{C}}_{2} \overline{\mathrm{x}}_{2}(\mathrm{k})$

$\overline{\mathrm{y}}_{2}(\mathrm{k})=\mathrm{H}_{12}^{\mathrm{T}} \overline{\mathrm{C}}_{2} \overline{\mathrm{x}}_{2}(\mathrm{k})=\mathrm{C}_{2} \overline{\mathrm{x}}_{2}(\mathrm{k})$

It should be noticed that:

$\overline{\mathrm{y}}_{1}(\mathrm{k})=\mathrm{G}_{\mathrm{s}}^{\mathrm{T}} \overline{\mathrm{y}}(\mathrm{k})$

with: $\mathrm{G}_{\mathrm{s}}^{\mathrm{T}}=\left(\begin{array}{cc}\mathrm{I}_{\mathrm{s}} & 0_{\mathrm{s} .(\mathrm{m}-\mathrm{s})}\end{array}\right) \in \mathrm{R}^{\mathrm{s} \cdot \mathrm{m}}$

As $R_{1}$ and $K_{1}^{T}$ are regular, one can deduce from (7a):

$\overline{\mathrm{x}}_{1}(\mathrm{k})=\mathrm{K}_{1} \mathrm{R}_{1}^{-1} \mathrm{G}_{\mathrm{s}}^{\mathrm{T}} \mathrm{H}_{1}^{\mathrm{T}}\left(\mathrm{y}(\mathrm{k})-\overline{\mathrm{C}}_{2} \overline{\mathrm{x}}_{2}(\mathrm{k})\right)$

Sustituting (9) into (5b) leads to:

$\overline{\mathrm{x}}_{2}(\mathrm{k}+1)=\mathrm{A}_{2} \overline{\mathrm{x}}_{2}(\mathrm{k})+\mathrm{B}_{2} \mathrm{u}(\mathrm{k})+\mathrm{D}_{2} \mathrm{y}(\mathrm{k})$

with:

$\mathrm{A}_{2}=\overline{\mathrm{A}}_{22}-\overline{\mathrm{A}}_{21} \mathrm{~K}_{1} \mathrm{R}_{1}^{-1} \mathrm{G}_{\mathrm{s}}^{\mathrm{T}} \mathrm{H}_{1}^{\mathrm{T}} \overline{\mathrm{C}}_{2}$

$\mathrm{B}_{2}=\overline{\mathrm{B}}_{2}$

$\mathrm{D}_{2}=\overline{\mathrm{A}}_{21} \mathrm{~K}_{1} \mathrm{R}_{1}^{-1} \mathrm{G}_{\mathrm{s}}^{\mathrm{T}} \mathrm{H}_{1}^{\mathrm{T}}$

After the elimination of the unknown inputs, the system is described by the state equation (10) and the measurement equation (7b). As suggested by Hou, following the conventional Luenberger observer design procedure, one can design a reduced-order observer for the unknown-input free system (10)-(7b). However, this design is conditioned by the detectability of the pair $\left\{\mathrm{A}_{2}, \mathrm{C}_{2}\right\}$. A full order observer can be written as:

$\stackrel{\wedge}{\mathrm{x}}_{2}(\mathrm{k}+1)=\left(\mathrm{A}_{2}-\mathrm{LC}_{2}\right) \stackrel{\wedge}{\mathrm{x}}_{2}(\mathrm{k})+\mathrm{B}_{2} \mathrm{u}(\mathrm{k})+\left(\mathrm{D}_{2}+\mathrm{LH}_{12}^{\mathrm{T}}\right)$ $\mathrm{y}(\mathrm{k})$

In order to obtain an estimation of the unknown inputs, one uses the definition (4c) and the equation (5a), in which the state $\overline{\mathrm{x}}_{1}(\mathrm{k})$ has to be eliminated:

$\hat{\mathrm{d}}(\mathrm{k})=\mathrm{K} \mathrm{R}^{-1}\left(\left(\mathrm{q} \mathrm{I}-\overline{\mathrm{A}}_{11}\right) \overline{\mathrm{x}}_{1}(\mathrm{k})-\overline{\mathrm{A}}_{12} \overline{\mathrm{x}}_{2}(\mathrm{k})-\overline{\mathrm{B}}_{1} \mathrm{u}(\mathrm{k})\right)(13)$

$\hat{\mathrm{d}}(\mathrm{k})=\alpha(\mathrm{q}) \mathrm{y}(\mathrm{k})+\beta(\mathrm{q}) \overline{\mathrm{x}}_{2}(\mathrm{k})+\gamma(\mathrm{q}) \mathrm{u}(\mathrm{k})$

with:

$\alpha(q)=K^{-1}\left(q I-\bar{A}_{11}\right) K_{1} R_{1}^{-1} G_{s}^{T} H_{1}^{T}$

$\beta(q)=-K^{-1}\left(\bar{A}_{12}+\left(q I-\bar{A}_{11}\right) K_{1} R_{1}^{-1} G_{s}^{T} H_{1}^{T} \bar{C}_{2}\right)(15 b)$

$\gamma(q)=-\mathrm{K} \mathrm{R}^{-1} \overline{\mathrm{B}}_{1}$

\section{Examples}

Let us consider the following discrete system:

$\mathrm{A}=\left(\begin{array}{ccc}-1 & 1 & 0 \\ -1 & 0 & 0 \\ 0 & -1 & -1\end{array}\right) \quad \mathrm{B}=\left(\begin{array}{c}1 \\ 0.5 \\ 1\end{array}\right) \quad \mathrm{C}=\left(\begin{array}{lll}1 & 0 & 0 \\ 0 & 0 & 1\end{array}\right) \quad \mathrm{D}=\left(\begin{array}{c}-1 \\ 0 \\ 0\end{array}\right)$

Following (2), it could be verified that:
$\mathrm{H}=\left(\begin{array}{ccc}-1 & 0 & 0 \\ 0 & 1 & 0 \\ 0 & 0 & 1\end{array}\right) \quad \mathrm{K}=1 \quad \mathrm{R}=1$

The change of variables (4) yields:

$\overline{\mathrm{A}}=\left(\begin{array}{ccc}-1 & -1 & 0 \\ 1 & 0 & 0 \\ 0 & -1 & -1\end{array}\right) \quad \overline{\mathrm{B}}=\left(\begin{array}{c}-1 \\ 0.5 \\ 1\end{array}\right) \quad \overline{\mathrm{C}}=\left(\begin{array}{ccc}-1 & 0 & 0 \\ 0 & 0 & 1\end{array}\right)$

and the state equations (5) are expressed:

$\overline{\mathrm{x}}_{1}(\mathrm{k}+1)=-\overline{\mathrm{x}}_{1}(\mathrm{k})+\left(\begin{array}{ll}-1 & 0\end{array}\right) \overline{\mathrm{x}}_{2}(\mathrm{k})-\mathrm{u}(\mathrm{k})+\mathrm{d}(\mathrm{k})$

$\overline{\mathrm{x}}_{2}(\mathrm{k}+1)=\left(\begin{array}{l}1 \\ 0\end{array}\right) \overline{\mathrm{x}}_{1}(\mathrm{k})+\left(\begin{array}{cc}0 & 0 \\ -1 & -1\end{array}\right) \overline{\mathrm{x}}_{2}(\mathrm{k})+\left(\begin{array}{c}0.5 \\ 1\end{array}\right) \mathrm{u}(\mathrm{k})$

$\mathrm{y}(\mathrm{k})=\left(\begin{array}{c}-1 \\ 0\end{array}\right) \overline{\mathrm{x}}_{1}(\mathrm{k})+\left(\begin{array}{cc}0 & 0 \\ 0 & 1\end{array}\right) \overline{\mathrm{x}}_{2}(\mathrm{k})$

The unknown input is estimated by:

$\hat{\mathrm{d}}(\mathrm{k})=-(\mathrm{q}+1) \mathrm{y}_{.1}(\mathrm{k})+\stackrel{\Delta}{\mathrm{x}}_{2.1}(\mathrm{k})+\mathrm{u}(\mathrm{k})$

where $\mathrm{z}_{. \mathrm{i}}$ denotes the $\mathrm{i}^{\mathrm{th}}$ entry of the vector $\mathrm{z}$.

In order to illustrate the non-applicability of the method proposed by Hou, let us consider the following fourthorder dynamic system described by:

$\mathrm{A}=\left(\begin{array}{cccc}-1 & 0 & -1 & 0 \\ 0 & 1 & 0 & 1 \\ 1 & 0 & 0 & 0 \\ 0 & 1 & 0 & -1\end{array}\right) \quad \mathrm{B}=\left(\begin{array}{c}-1 \\ 0 \\ 0.5 \\ 0\end{array}\right) \quad \mathrm{C}=\left(\begin{array}{cccc}-1 & 1 & 0 & 0 \\ 0 & 0 & 0 & 1\end{array}\right) \quad \mathrm{D}=\left(\begin{array}{cc}1 & 0 \\ 0 & 0.5 \\ 0 & 0 \\ 0 & 0\end{array}\right)$

For this example, it is clear that:

$\overline{\mathrm{C}}_{1}=\left(\begin{array}{cc}-1 & 1 \\ 0 & 0\end{array}\right)$

As $\overline{\mathrm{C}}_{1}$ is not a full column rank matrix the decomposition (6) does not hold and the deduction of the sub-state $\bar{x}_{2}(\mathrm{k})$ from the measurement equation is not possible. However, the estimation of the unknown input may be achieved. Indeed from the decomposition (5) one obtains:

$$
\begin{array}{r}
\overline{\mathrm{x}}_{1}(\mathrm{k}+1)=\left(\begin{array}{cc}
-1 & 0 \\
0 & 1
\end{array}\right) \overline{\mathrm{x}}_{1}(\mathrm{k})+\left(\begin{array}{cc}
-1 & 0 \\
0 & 1
\end{array}\right) \overline{\mathrm{x}}_{2}(\mathrm{k}) \\
+\left(\begin{array}{c}
-1 \\
0
\end{array}\right) \mathrm{u}(\mathrm{k})+\left(\begin{array}{cc}
1 & 0 \\
0 & 0.5
\end{array}\right) \overline{\mathrm{d}}(\mathrm{k})
\end{array}
$$

$\overline{\mathrm{x}}_{2}(\mathrm{k}+1)=\left(\begin{array}{cc}1 & 0 \\ 0 & 1\end{array}\right) \overline{\mathrm{x}}_{1}(\mathrm{k})+\left(\begin{array}{cc}0 & 0 \\ 0 & -1\end{array}\right) \overline{\mathrm{x}}_{2}(\mathrm{k})+\left(\begin{array}{c}0.5 \\ 0\end{array}\right) \mathrm{u}(\mathrm{k})$

$\mathrm{y}(\mathrm{k})=\left(\begin{array}{cc}-1 & 1 \\ 0 & 0\end{array}\right) \bar{x}_{1}(\mathrm{k})+\left(\begin{array}{cc}0 & 0 \\ 0 & 1\end{array}\right) \overline{\mathrm{x}}_{2}(\mathrm{k})$

Then, equation (16b) allows $\overline{\mathrm{x}}_{1}(\mathrm{k})$ to be expressed as a function of $\overline{\mathrm{x}}_{2}(\mathrm{k})$ and $\mathrm{u}(\mathrm{k})$; therefore, from (16c), $\overline{\mathrm{x}}{ }_{2}(\mathrm{k})$ may be deduced.

$\overline{\mathrm{x}}_{2}(\mathrm{k})=-\frac{1}{\mathrm{q}}\left(\begin{array}{cc}1 & -(\mathrm{q}+1) \\ 0 & -\mathrm{q}\end{array}\right) \mathrm{y}(\mathrm{k})+\frac{1}{\mathrm{q}}\left(\begin{array}{c}0.5 \\ 0\end{array}\right) \mathrm{u}(\mathrm{k})$ 
$\bar{x}_{1}(k)=\left(\begin{array}{cc}-1 & q+1 \\ 0 & q+1\end{array}\right) y(k)$

Substituting the state variables in (16a), the expression of the unknown input is obtained as:

$$
\bar{d}(k)=\left(\begin{array}{cc}
-\left(\mathrm{q}+1+\frac{1}{\mathrm{q}}\right) & \frac{(\mathrm{q}+1)\left(\mathrm{q}^{2}+\mathrm{q}+1\right)}{\mathrm{q}} \\
0 & 2\left(\mathrm{q}^{2}-2\right)
\end{array}\right) \mathrm{y}(\mathrm{k})+\left(\begin{array}{c}
1+\frac{0.5}{\mathrm{q}} \\
0
\end{array}\right) \mathrm{u}(\mathrm{k})
$$

\section{The proposed solution}

In the case where the matrix $\overline{\mathrm{C}}_{1}$ is not of full row rank, the decomposition (6) is not available. In order to be independent of this hypothesis, consider once again the equations (5). They form a linear system in respect with the states $\overline{\mathrm{x}}_{1}(\mathrm{k}), \overline{\mathrm{x}}_{2}(\mathrm{k})$ and the unknown inputs $\mathrm{d}(\mathrm{k})$. As $\mathrm{R}$ is a regular matrix and due to the fact that $\bar{d}(\mathrm{k})$ is only present in equation (5a), this equation may be used to estimate $\overline{\mathrm{d}}(\mathrm{k})$. The remaining equations $(5 \mathrm{~b})$ and $(5 \mathrm{c})$ are then used to determine the states $\overline{\mathrm{x}}_{1}(\mathrm{k})$ and $\overline{\mathrm{x}}_{2}(\mathrm{k})$. A global approach for this estimation may be achieved by rewriting the system (5) as:

$\mathrm{N}\left(\begin{array}{l}\overline{\mathrm{x}}_{1}(\mathrm{k}) \\ \overline{\mathrm{x}}_{2}(\mathrm{k})\end{array}\right)=\mathrm{N}\left(\begin{array}{c}\mathrm{u}(\mathrm{k}) \\ \mathrm{y}(\mathrm{k})\end{array}\right)+\mathrm{P} \overline{\mathrm{d}}(\mathrm{k})$

with:

$\mathrm{M}=\left(\begin{array}{cc}-\overline{\mathrm{A}}_{21} & \mathrm{qI}-\overline{\mathrm{A}}_{22} \\ \overline{\mathrm{C}}_{1} & \overline{\mathrm{C}}_{2} \\ \mathrm{qI}-\overline{\mathrm{A}}_{11} & -\overline{\mathrm{A}}_{12}\end{array}\right), \quad \mathrm{N}=\left(\begin{array}{c}\overline{\mathrm{B}}_{2} 0 \\ 0 \mathrm{I} \\ \overline{\mathrm{B}}_{1} 0\end{array}\right), \quad \mathrm{P}=\left(\begin{array}{l}0 \\ 0 \\ \mathrm{R}\end{array}\right)$

If $\Omega(q)=\left(\omega_{1}(q) \quad \omega_{2}(q) \quad \omega_{3}(q)\right)$ is a matrix orthogonal to $\mathbf{M}$ (this is not a tedious task because $\mathrm{M}$ is a binomial matrix (Gantmacher, 1959)), one may deduce from (19) the relationship between the unknown inputs $\overline{\mathrm{d}}(\mathrm{k})$ and the known inputs and outputs $\mathrm{u}(\mathrm{k})$ and $\mathrm{y}(\mathrm{k})$ :

$\Omega(\mathrm{q})\left(\mathrm{N}\left(\begin{array}{l}\mathrm{u}(\mathrm{k}) \\ \mathrm{y}(\mathrm{k})\end{array}\right)+\mathrm{P} \overline{\mathrm{d}}(\mathrm{k})\right)=0$

or with an appropriate partitioning of $\Omega$ :

$\left.\left(\omega_{1}(\mathrm{q}) \overline{\mathrm{B}}_{2}+\omega_{3}(\mathrm{q}) \overline{\mathrm{B}}_{1}\right)\right) \mathrm{u}(\mathrm{k})+\omega_{2}(\mathrm{q}) \mathrm{y}(\mathrm{k})+\omega_{3}(\mathrm{q}) \mathrm{R} \overline{\mathrm{d}}(\mathrm{k})=$ 0

The unknown inputs are then estimated after analysing the rank of the polynomial matrix $\omega_{3}(\mathrm{q}) \mathrm{R}$. For the proposed example, one obtains:

$M=\left(\begin{array}{cccc}-1 & 0 & q & 0 \\ 0 & -1 & 0 & q+1 \\ -1 & 1 & 0 & 0 \\ 0 & 0 & 0 & 1 \\ q+1 & 0 & 1 & 0 \\ 0 & q-1 & 0 & -1\end{array}\right) N=\left(\begin{array}{ccc}0.5 & 0 & 0 \\ 0 & 0 & 0 \\ 0 & 1 & 0 \\ 0 & 0 & 1 \\ -1 & 0 & 0 \\ 0 & 0 & 0\end{array}\right) P=\left(\begin{array}{ll}0 & 0 \\ 0 & 0 \\ 0 & 0 \\ 0 & 0 \\ 1 & 0 \\ 0 & 0.5\end{array}\right)$
For example, the following matrix $\Omega$ is orthogonal to $\mathrm{M}$ :

$$
\Omega=\left(\begin{array}{cccccc}
0 & q-1 & 0 & 2-q^{2} & 0 & 1 \\
1 & -\left(1+q+q^{2}\right) & -\left(1+q+q^{2}\right) & (1+q)\left(1+q+q^{2}\right) & -q & 0
\end{array}\right)
$$

With:

$$
\mathrm{N}\left(\begin{array}{c}
\mathrm{u}(\mathrm{k}) \\
\mathrm{y}(\mathrm{k})
\end{array}\right)+\mathrm{P} \overline{\mathrm{d}}(\mathrm{k})=\left(\begin{array}{c}
0.5 \mathrm{u}(\mathrm{k}) \\
0 \\
\mathrm{y}_{.1}(\mathrm{k}) \\
\mathrm{y}_{.2}(\mathrm{k}) \\
-\mathrm{u}(\mathrm{k})+\overline{\mathrm{d}}_{.1}(\mathrm{k}) \\
0.5 \overline{\mathrm{d}}_{.2}(\mathrm{k})
\end{array}\right)
$$

one may verify that the equation (21) allows one to obtain directly the estimations (18) of $\mathrm{d}(\mathrm{k})$ founded from the state equations of the system.

\section{References}

J. Chen, H. Zhang. Robust detection of faulty actuators via unknown input observers. Int. J. Sciences, 22 (10), p. 18291839, 1991.

F.R. Gantmacher. The theory of matrices. Chelsea Publishing Company, 1959.

D. Gleason, D. Andrisani. Observer design for discrete systems with unknown exogeneous inputs. IEEE Trans. on Automatic Control, 35 (8), p. 932-935, 1990.

Y. Guan, M. Saïf. A novel approach to the design of unknown input observers. IEEE Trans. on Automatic Control, 36 (5), p. 632-635, 1991.

G. Hostetter, J.S. Meditch. Observing systems with unmeasurable inputs. IEEE Trans. on Automatic Control, 18, p. 307-308, 1973.

M. Hou, P.C. Müller. Design of observers for linear systems with unknown inputs. IEEE Trans. on Automatic Control, 37 (6), p. 871-875, 1992.

C.D. Johnson. On observers for linear systems with unknown and inacessible inputs. Int. J. Control, 37 (6), p. 871-875, 1992.

H. Kobayashi, T. Nakamizo. An observer design for linear systems with unknown inputs. Int. J. Control, 35 (4), p. 605619, 1982 .

J.E. Kurek. The state vector reconstruction for linear systems with unknown inputs. IEEE Trans. on Automatic Control, 28 (12), p. 1120-1122, 1983.

R.J. Miller, R. Mukundan. On designing reduced-order observers for linear non-invariant systems subject to unknown inputs. Int. J. Control, 35 (1), p. 183-188, 1982.

J. Park, J.L. Stein. Closed-loop, state and input observer for systems with unknown inputs. Int. J. Control, 48 (3), p. 1121-1136, 1988.

N. Viswanadham, R. Srichander. Fault detection using unknown input observers. Control Theory and Advanced Technology, 3 (2), p. 91-101, 1987. 
F. Yang, R.W. Wilde. Observer for linear systems with unknown inputs. IEEE Trans. on Automatic Control, 33 (7), p. 677-681, 1988.

C.W. Yang, H.L. Tan. Observer design for singular systems with unknown inputs. Int. J. Control, 49 (6), p. 1937-1946, 1989. 